\title{
VAT Dispute Case Analysis PT. State Gas Company Tbk.
}

\author{
${ }^{*}$ Rahmat \\ ${ }^{* *}$ Ratih Ayu Yuniarti \\ ${ }^{*}$ BC202120210 \\ ${ }^{* * *} \mathrm{BC} 211120005$ \\ DOI: 10.29322/IJSRP.12.01.2022.p12155 \\ http://dx.doi.org/10.29322/IJSRP.12.01.2022.p12155
}

\begin{abstract}
Tax dispute is a dispute that arises in the field of taxation between a Taxpayer or Tax insurer and an authorized official as a result of the issuance of a decision that can be appealed or sued to the Tax Court based on tax laws and regulations, including a lawsuit on the implementation of collection based on the Tax Collection Law. with a Forced Letter, In 2020 PT. Perusahaan Gas Negara Tbk, Experiencing a VAT tax dispute

In the Consolidated Financial Statements of PT. Perusahaan Gas Negara Tbk in 2020 DGT claims that PT Perusahaan Gas Negara Tbk has provided a tax dispute provision of US\$294.3 million, the provision includes expenses for 24 VAT disputes of Rp 4.15 Trillion and US\$ 15.9 million as a loss on the different exchange rate
\end{abstract}

Index Terms- tax dispute, PT Perusahaan Gas Negara

\section{BACKGROUND}

$\mathrm{T}^{\mathrm{m}}$ The essence of the relationship between the State and the people as citizens is a symbiotic relationship - mutualism, that both need each other, there is dependence on one another. The state needs the people for the continuity of the running of power or government, and the people need the protection of the state to ensure their rights as citizens. In the opinion of Prof. Harold J. Laski, the state is a society that is integrated because it has a coercive and legitimate authority that is greater than the individuals or groups that are part of that group.

In carrying out government functions, especially in the field of sources of state financial financing for the welfare of the community, the government or the state requires sources of state financial revenues as the preparation of the state budget items for the current fiscal year, which are obtained from levies or contributions from citizens. sources of State financial income come from among others from Taxes; Oil and Gas; Other foreign exchange; and Foreign Loans.

The tax sector provides the largest contribution to the state's financial revenue budget. The higher the level of economic growth of a nation, the higher the contribution of taxes to the state's financial revenues. Tax is a mandatory levy by the state to its citizens for financing or state expenditures.

In Indonesia, as the largest source of state revenue and expenditure budget revenues, tax collection often creates disputes. These tax disputes often arise or arise, among others, due to misperceptions in understanding tax regulations, differences in accounting and financial systems, and conflicting tax regulations between countries that at present Finally, there is a difference in the determination of the tax rate imposed on the taxpayer. This is because, in the tax collection technique, Indonesia adheres to a Self Assessment System, which is a system in which taxpayers are invited to actively participate and be responsible for their respective taxes, namely taxpayers are asked to calculate, calculate, pay and report the tax payable themselves. Conflicts or disputes that occur in terms of tax calculations, usually originate from the results of an examination conducted by the DirectorGeneral of Taxes as the implementation of supervision over taxpayer compliance with laws and regulations, especially laws and regulations in the field of taxation.

The process of resolving this tax dispute will take a long time because the results of the examination carried out by the Director-General of Taxes who produce the Tax Assessment Letter must be submitted and approved by the taxpayer in writing. The Rp 3.06 trillion tax dispute case between PT Perusahaan Gas Negara (Persero) Tbk or PGN and the Directorate General of Taxes (DJP) of the Ministry of Finance surfaced earlier this year. The re-emergence of this case to the surface is a continuation of the request by the Indonesia Stock Exchange (IDX) to PGN to explain on December 18, 2020. Then, on December 30, 2020, PGN Corporate Secretary Rachmat Hutama responded to this IDX request and told the chronology of the dispute that occurred. First, the 2012 tax dispute relates to differences in interpretation in understanding tax provisions, namely: PMK-252/PMK.011/2012 (PMK) on the implementation of the obligation to collect VAT on the delivery of natural gas.

Second, the 2013 dispute relates to differences in understanding of the Company's billing mechanism. In June 1998, the company set the gas price at US\$/MMBTU and Rp/M3 due to the weakening of the exchange rate of Rp to US\$. Meanwhile, previously, the gas price was only Rp/M3. However, the DGT thinks that the portion of the Rp/M3 price is a replacement for distribution services subject to VAT. Meanwhile, the company thinks that the price in US\$/MMBTU and Rp/M3 is a single unit of the gas price which is not subject to VAT.

So for the dispute, the DGT issued 24 Underpaid Tax Assessment Letters (SKPKB) with a total value of Rp. 4.15 Trillion for 24 tax periods. But apart from that, there are also disputes for other types of taxes for the period 2012-2013 through the issuance of 25 SKPKB with a total value of Rp. 2.22 billion. 
Thus, the company filed an objection, but the DGT rejected the request. Furthermore, in 2018, the company filed an appeal through the Tax Court. In 2019, the Tax Court decided to grant all of the company's appeals and cancel the DGT's decision on 49 SKPKB. But in 2019, the DGT submitted a judicial review (PK) to the Supreme Court. As a result, the Supreme Court granted the application submitted by the DGT, but with a disputed value of Rp. 3.06 trillion. However, the company has not yet received a copy of the Supreme Court's decision by the procedures stipulated in the Supreme Court Law.

The tax case related to the PT Perusahaan Gas Negara Tbk Tax Dispute is interesting to discuss. The DGT, as the Indonesian tax authority, can take a valuable lesson from the PT Perusahaan Gas Negara Tbk Tax Dispute case. In this paper, the author will analyze the case of the Tax Dispute of PT. Perusahaan Gas Negara Tbk, Legal Efforts made by PT Perusahaan Gas Negara Tbk in this case, as well as problem-solving strategies to deal with cases of VAT tax disputes in the future.

\section{QUESTION}

The questions in writing this paper are as follows:

1. How is the tax case related to the VAT Tax dispute that occurred at PT. Perusahaan Gas Negara Tbk?

2. What are the Legal Efforts made by PT. Perusahaan Gas Negara Tbk for related Tax Dispute cases?

3. What is the strategy of PT. Perusahaan Gas Negara Tbk in dealing with related Tax Dispute cases?

\section{THEORY BASIS}

Definition of the term Tax Case.

In this paper, the author will explain the terms or

The meanings in the related cases include:

a. Tax is the people's contribution to the State treasury based on a law that can be enforced by not getting any remuneration or counter-performance services that can be directly demonstrated and which are used to pay for general expenses.

b. Taxpayers are individuals or entities including taxpayers, withholding tax collectors and tax collectors, who have tax rights and obligations under with the provisions of tax laws and regulations 18

c. Tax payable is a debt that arises at the time a decision is issued taxes by the government to taxpayers.

d. Tax Disputes are Disputes that arise in the field of taxation between taxpayers taxes with the competent authorities due to misperceptions in understand tax regulations, differences in accounting and financial systems, and clash of tax regulations between countries which in the end there are differences in determining the tax rate imposed on taxpayers.

e. The Tax Court is a judicial body that exercises judicial power for taxpayers or tax bearers seeking justice for disputes tax.

f. An appeal is a legal remedy that can be taken by a taxpayer against a decision that can be appealed, based on the applicable tax laws and regulations. g. A lawsuit is a legal remedy that can be taken by a taxpayer against a implementation of tax collection or against decisions that can be filed a lawsuit based on the applicable tax laws and regulations.

h. Attorney is a person who is given a special power of attorney to represent the parties disputing parties, the number of which can be one or more.

i. The letter of a description of the appeal is the letter of appeal to the tax court which contains answers to the reasons for the appeal submitted by the appellant.

j. Response Letter is a letter from the defendant to the Tax Court which contains: response to the lawsuit filed by the plaintiff.

$\mathrm{k}$. A letter of rebuttal is a letter from an appeal applicant or plaintiff to Tax Court containing a rebuttal to the letter of appeal or letter of appeal Response.

1. The date received is the date of the postage stamp, the date of the fax, or in the case of being received directly is the date when the decision letter or decisions are accepted immediately.

m. The date sent is the date of the postage stamp, the date of the fax, or in the case of being received directly is the date when the decision letter or decisions are delivered directly.

n. Decision is a written determination in the field of taxation issued by the competent authority based on the tax laws and regulations in the framework of implementing the Law on Tax Collection by Forced Letters.

o. Quick Event Inspection is an inspection process carried out by The panel or sole judge in the case of certain tax disputes, and the lawsuit is decided in a period of fewer than 6 months.

p. Examination by Ordinary Procedure is an inspection process carried out by Tribunal as usual in the case of tax disputes and the lawsuit is decided in 6 months from the date of receipt of the claim.

q. The Panel of Judges is the judge who presides over the trial appointed by President with a proposal from the minister.

r. Sole Judge is a Judge appointed by the Chairman to examine and resolve Tax Disputes with a quick event.

s. Member Judge is a Judge in a panel appointed by the Chairperson to become a member of the assembly.

t. Chief Judge is a member Judge appointed by the Chairperson to preside hearing.

u. Secretaries, deputy secretaries and alternate secretaries are secretaries, representatives secretaries and alternate secretaries at the Tax Court.

v. The Registrar, Deputy Registrar and Substitute Registrar are secretaries, deputy secretaries and substitute secretary at the Tax Court. that performs the function secretariat.

\section{VAT Dispute Issues at PT. Perusahaan Gas Negara Tbk.}

PT Perusahaan Gas Negara Tbk (PGAS) or known as PGN recorded revenues of USD 2.88 billion in 2020 or around IDR 42.07 trillion (assuming an exchange rate of IDR 14,582 per US 
dollar). This revenue realization decreased by 25.02 per cent from the 2019 period of USD 3.84 billion.

PGN experienced a loss for the year attributable to owners of the parent entity of USD 264.77 million in 2020.

This amount is different from the 2019 period of USD 67.58 million profit. Thus, the loss per share attributable to the owners of the basic and diluted parent entity (0.011) in 2020 from the same period in the previous year was 0.003 .

PGN's Finance Director, Arie Nobelta Kaban said, 2020 was a year full of challenges for the company. This is due to the uncertainty of global and national conditions due to the COVID19 pandemic which greatly impacted performance during 2020.

Arie added, regarding the 2020 financial performance, which suffered losses mainly due to external factors such as tax disputes regarding VAT in the 2012-2013 period, which were submitted by the Directorate General of Taxes (DGT) through judicial review (PK) and there was a decision of the Supreme Court (MA). ) in December 2020 of USD 278.4 million. In addition, there was a decrease in assets in the oil and gas sector by USD 78.9 million. The company stated that without the two factors beyond management's control above, PGN's financial performance would still record a net profit of USD 92.5 million. This profit is still higher than the net profit attributable to the parent entity of USD 67.5 million in 2019 Management has made various efforts to

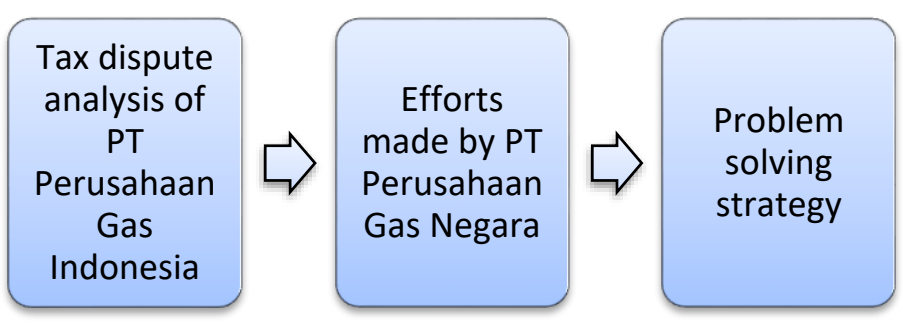

maintain the company's performance, including tax disputes at the Supreme Court.

\section{Framework}

Framework for writing this paper. The author will analyze the tax dispute case of PT Perusahaan Gas Negara Tbk. From the results of the analysis of the VAT Dispute case of PT Perusahaan Gas Negara, we will find out the Legal Efforts made by PT. Perusahaan Gas Negara Tbk in this case. Furthermore, the author will try to provide a problem-solving strategy for PT. Perusahaan Gas Negara Tbk to deal with cases of VAT Tax Disputes in the future.

\section{Picture}

Framework

\section{RESEARCH METHOD}

\section{C.1 Type of Research}

This research is qualitative.

\section{C.2 Data Collection Techniques}

The data collection technique used in this research is a literature study. The author analyzes books, scientific journals, and mass media reports related to the VAT dispute case of PT Perusahaan Gas Negara Tbk. In addition to doing library research.

\section{C.3 Data Analysis Techniques}

To answer the research problem, the author uses qualitative data analysis techniques to produce analytical-descriptive data. This analysis was chosen because it is very flexible and facilitates the search for ideas and clues regarding the problem situation.

\section{DISCUSSION AND DISCUSSION}

1. Case Analysis of the Tax Dispute of PT Perusahaan Gas Negara.

The Rp 3.06 trillion tax dispute case between PT Perusahaan Gas Negara (Persero) Tbk or PGN and the Directorate General of Taxes (DJP) of the Ministry of Finance surfaced earlier this year. The re-emergence of this case to the surface is a continuation of the request by the Indonesia Stock Exchange (IDX) to PGN to explain on December 18, 2020. Then, on December 30, 2020, the Corporate Secretary of PGN responded to this IDX request and told the chronology of the dispute that occurred.

PGN's tax dispute with the DGT related to transactions in 2012 and 2013. Which have been reported in the notes to the Company's Financial Statements as of December 31, 2017, onwards. First, the 2012 tax dispute relates to differences in interpretation in understanding the tax provisions, namely PMK252/PMK.011/2012 (PMK) on the implementation of the obligation to collect VAT on the delivery of natural gas. Second, the 2013 dispute relates to differences in understanding of the Company's billing mechanism. In June 1998, the company set the gas price at US\$/MMBTU and Rp/M3 due to the weakening of the exchange rate of Rp to US\$. Meanwhile, previously, the gas price was only $\mathrm{Rp} / \mathrm{M} 3$.

However, the DGT thinks that the portion of the Rp/M3 price is a replacement for distribution services subject to VAT. Meanwhile, the company thinks that the price in US\$/MMBTU and $\mathrm{Rp} / \mathrm{M} 3$ is a single unit of the gas price which is not subject to VAT.

So for the dispute, the DGT issued 24 Underpaid Tax Assessment Letters (SKPKB) with a total value of Rp. 4.15 Trillion for 24 tax periods. But apart from that, there are also disputes for other types of taxes for the period 2012-2013 through the issuance of 25 SKPKB with a total value of Rp. 2.22 billion.

Thus, the company filed an objection, but the DGT rejected the request. Furthermore, in 2018, the company filed an appeal through the Tax Court. In 2019, the Tax Court decided to grant all of the company's appeals and cancel the DGT's decision on 49 SKPKB. But in 2019, the DGT submitted a judicial review (PK) to the Supreme Court. As a result, the Supreme Court granted the application submitted by the DGT, but with a disputed value of Rp. 3.06 trillion. However, the company has not yet received a copy of the Supreme Court's decision by the procedures stipulated in the Supreme Court Law.

Then PT Perusahaan Gas Negara Tbk (PGAS) or known as PGN recorded revenues of USD 2.88 billion in 2020 or around IDR 42.07 trillion (assuming an exchange rate of IDR 14,582 per US dollar). This revenue realization decreased by 25.02 per cent from the 2019 period of USD 3.84 billion. PGN experienced a loss 
for the year attributable to owners of the parent entity of USD 264.77 million in 2020.

This amount is different from the 2019 period of USD 67.58 million profit. Thus, the loss per share attributable to the owners of the basic and diluted parent entity (0.011) in 2020 from the same period in the previous year was 0.003. 2020 was a year full of challenges for the company. This is due to the uncertainty of global and national conditions due to the COVID-19 pandemic which greatly impacted performance during 2020.

Regarding financial performance in 2020, which experienced losses, mainly due to external factors such as tax disputes regarding VAT in the period 2012-2013 which were submitted by the Directorate General of Taxes (DGT) through judicial review (PK) and there was a Supreme Court (MA) decision on December 2020 amounted to USD 278.4 million. In addition, there was a decrease in assets in the oil and gas sector by USD 78.9 million.

The company stated that without the two factors beyond management's control above, PGN's financial performance would still record a net profit of USD 92.5 million. This profit is still higher than the net profit attributable to the parent company of USD 67.5 million in 2019. Management has made various efforts to maintain the company's performance, including tax disputes in the Supreme Court.

\section{Legal Efforts made in dealing with tax disputes}

Regarding the Supreme Court tax dispute, the company explained several things while still taking legal efforts, including:

1. The case of PGN's VAT tax ruling is specific for 2012-2013.

2. In 2014, until now, the VAT dispute case was won by PGN or determined that natural gas was not an object of VAT according to the DGT's letter in January 2020.

3. Legal efforts undertaken include:

- MA fatwa for 18 cases that have been decided

- For the remaining six cases that are still ongoing, PGN will implement a PK counter-memory, with the addition of the counter-memory, it is hoped that the dispute that has not been decided will be won by PGN.

- Request for expert opinion and state attorney (Jamdatun) as the authorized party.

- Submit a letter of request for justice to the Chief Justice of the Supreme Court

4. Request a non-executable fatwa because natural gas is not a VAT tax subject according to the provisions of the tax law and the tax period has expired (20122013).

5. The company's last resort after receiving a bill from the DGT, as a mandatory collection, PGN will forward the bill to the customer.

With this legal effort, it is hoped that it will get a reverse tax and certainty of incentives from the implementation of government assignments.

\section{Problem-solving strategies in dealing with tax disputes}

Source: liputan6.com, Jakarta

In connection with the assignment of implementing the USD 6/MMBTU price policy through Kempen 89.K/2020 and Kempen 91.K/2020, the government has agreed to provide incentives to PGN as stated in Ministerial Regulation 8/2020 and Ministerial Regulation 10/2020.

The form of incentives that will be given to PGN is still under discussion with the Government. About the decline (impairment) of oil and gas assets, Management will optimize assets to support business sustainability and security of supply. To maintain business sustainability, PGN has pursued several future strategies, including:

a. Integration of upstream-downstream pipeline infrastructure as well as PGN and Partagas gas pipelines.

b. Business Transformation and restructuring of Subsidiaries.

c. Completion of the Rokan Pipeline network construction.

d. Construction of the small land-based LNG regasification terminal RU Cilacap.

e. Construction of the Senipah Balikpapan pipeline network to support gas supply to RU Balikpapan.

f. Completion of the conversion of PLN's diesel to gas generators under Kempen 13.

g. LNG infrastructure development for domestic smelters. It is hoped that from the long-term efforts and strategies that will be implemented, in 2021 PGN will get a reserve tax, the realization of incentives, operational benefits, efficiency, and optimization of CAPEX and OPEX, which leads to profit and performance improvement.

\section{CONCLUSION}

The things that can be concluded from this paper are as follows:

1. Tax dispute is a dispute that arises in the field of taxation between a Taxpayer or Tax Insurer and an authorized official as a result of the issuance of a decision that can be filed for an appeal or a lawsuit to the Tax Court based on the tax laws and regulations, including a lawsuit on the implementation of collection based on the law Tax Collection by Forced Letter.

2. Tax dispute has several terms, namely Appeal, Lawsuit, Description of Appeal, Response Letter, Rebuttal Letter, Examination and Decision.

3. DGT thinks that the portion of the $\mathrm{Rp} / \mathrm{M} 3$ price is a replacement for distribution services subject to VAT. Meanwhile, the company thinks that 
the price in US\$/MMBTU and Rp/M3 is a single unit of the gas price which is not subject to VAT. Therefore, the DGT issued 24 Underpaid Tax Assessment Letters (SKPKB).

4. To settle the case, the company filed an objection, but the DGT rejected the request. Furthermore, in 2018, the company filed an appeal through the Tax Court. In 2019, the Tax Court decided to grant all of the company's appeals and cancel the DGT's decision on 49 SKPKB. But in 2019, the DGT submitted a judicial review (PK) to the Supreme Court.

5. The strategy used by PGN is to obtain reserve tax, the realization of incentives, operational profit, efficiency, and optimization of CAPEX and OPEX, which lead to profit and performance improvement

\section{REFERENCES}

[1] https://business.tempo.co/read/1420196/begini-kronologi-sengketa-pajakrp-306-triliun-antara-pgn-dan-ditjen-pajak.

[2] http://m.liiputan6.com/saham/read/4530447/usaha-pgn-hadapi-sengketapajak.

[3] Sofrin Sofyan and Asyar Hidayat, "Tax Law and its Problems" Refika Aditama, Bandung, 2004, p.

[4] Soerjono Soekanto, Log City, page 132

[5] R Santoso Brotodihardjo, Log City, p.6 Handbook "Rights and Obligations of Taxpayers", Director General of Taxes, Jakarta, 2008.p.7

[6] Heru Suyanto, "Tax Law Lectures", UPN Veterans, Jakarta, 2010, page 220 Indonesia, Law No. 14 of 2002 concerning the "Tax Court" Karya Gemilang, Jakarta, 2008, page $521 \mathrm{Ibid}$, p. 7

[7] https://media.neliti.com/media/publications/167830-ID-penyelesaiansengketa-pajak.pdf

\section{AUTHORS}

First Author - Rahmat (BC202120210)

Second Author - Ratih Ayu Yuniarti (BC211120005) 